Review Article

\title{
IMMUNOMODULATOR ACTIVITY OF MANGIFERIN FROM MANGO (MANGIFERA INDICA L.) IN CANCER: A SYSTEMATIC REVIEW
}

\author{
YACHI QURRATA AYUNI LUBAKISAR, FITRA FAUZIAH*, REZLIE BELLATASIE
}

Department of Pharmacology and Clinical Pharmacy, School of Pharmaceutical Science (STIFARM) Padang, West Sumatra, Indonesia, 25147

*Email: fitrafauziah@stifarm-padang.ac.id

Received: 17 May 2021, Revised and Accepted: 20 Aug 2021

\section{ABSTRACT}

Cancer is a disease that is causing an increase in mortality all over the world. Cancer treatment is expensive and has a variety of side effects. Natural compound treatment is an attempt to reduce the side effects of cancer therapy. Mangiferin is a natural compound with anticancer and immunomodulatory activity. The immunomodulatory activity of mangiferin from mango (Mangifera indica L.) in cancer was discussed in this article.

The literature used in this review was obtained from several databases, including the Cochrane Library, Google Scholar, PubMed, ProQuest, ScienceDirect, and the Wiley Online Library, for articles published over the last ten years.

Mangiferin influenced anticancer activity by inhibiting NF- $\kappa \mathrm{B}$, affects the regulation of $\beta$-catenin, EMT, MMP2, MMP9, LDH, NO, ROS, and inhibits classical macrophages activation.

Mangiferin has an immunomodulatory effect that can be developed as a candidate drug for anticancer therapy.

Keywords: Cancer, Immune, Mangiferin, Mango

(C) 2021 The Authors. Published by Innovare Academic Sciences Pvt Ltd. This is an open-access article under the CC BY license (https://creativecommons.org/licenses/by/4.0/] DOI: https://dx.doi.org/10.22159/ijpps.2021v13i10.42095. Journal homepage: https://innovareacademics.in/journals/index.php/ijpps.

\section{INTRODUCTION}

Cancer is a disease that has a high prevalence worldwide. Cancer treatment requires high costs and various side effects that can affect the quality of life $[1,2]$. Cancer ranks first cause of death in every country. In 2019, cancer was the leading cause of death under the age of 70 . Based on the WHO report, in 2020, there be 19.3 million cancer cases and almost 10 million cancer deaths [3].

Currently, cancer treatment is experiencing rapid development with the hope of decreasing cancer mortality. One of the cancer treatments is immunotherapy [4]. Food and Drug Administration (FDA) approved immunotherapy drugs for cancer, namely vemurafenib, and ipilimumab. Vemurafenib works by inhibiting the b-rapidly accelerated fibrosarcoma (BRAF) protein, and the ipilimumab activates the immune system [5]. Immunomodulators are natural and adaptive compounds that can modulate the immune response. Immunomodulators are classified as adjuvants, suppressants and stimulants [6]. Stimulant-type immunomodulators in cancer restore the damaged immune system by activating the body's defense mechanisms [7].

In cancer, various immune responses are activated to avoid damage to the immune system [8]. Cancer cells will detect immune cells likes $\mathrm{T}$ cells and macrophages, resulting in increased levels of proinflammatory cytokines that stimulate $N F-\kappa B$ activation and encourage proliferation and metastasis [9]. T cells play an essential role in immune and antitumor responses, while B cells help in producing antibodies [10]. $\mathrm{T}$ cell receptor (TCR) and CD3 gene increase TCR expression leading to faster tumor clearance $[11,12]$.

Many drugs derived from plants are sensitive and effective against tumor development, prolong patients' survival time, and prevent side effects of chemotherapy [13-15]. One of them is mango (Mangifera indica L.) which belongs to the Anacardiaceae family, widely used as food, cosmetics, and medicine (16]. It is found in tropical and subtropical regions and is one of the most popular fruits with low calories and high fiber $[17,18]$. Mango contains polyphenol compounds (40-60\%), a potentially therapeutic phytochemical compound (19]. Various studies had shown that polyphenols have anti-inflammatory and immunomodulatory [20,21]. Polyphenol can also protect DNA from gamma-ray damage, which suggests that polyphenols act as radioprotection [22]. In mango, the most well-known compound is mangiferin [23]<smiles>CC(CO)[C@@H](O)[C@H](O)[C@H](C)O</smiles>

Fig. 1: Chemical structure of mangiferin

Mangiferin compounds (1,3,6,7-tetrahydroxyflavonoid-C2- $\beta$-Dglucoside) (fig. 1) are the compounds derived from the leaves and skin of mango $[24,25]$. Several studies have shown that the natural compound mangiferin has an anticancer activity where this compound can increase the sensitivity of cancer cells to anticancer drugs [26, 27]. Mangiferin also showed anti-inflammatory, antidiabetic, antioxidants, hypolipidemic, antiviral, immunomodulators, analgesics, and hepatoprotective activity [28-30]. Studies show that mangiferin has an immunomodulatory on T-cells and B-cells [31]. So far, there is no clinical evidence of side effects of mangiferin. This compound could be a candidate in drug development [32]. This article aims to summarize the immunomodulatory activity of mangiferin compounds in cancer.

\section{Method of collecting data}

A comprehensive search was carried out by collecting publications from several databases, i.e., Cochrane Library, Google Scholar, PubMed, ProQuest, ScienceDirect, and the Wiley Online Library. The keywords used were "(cancer) AND (mangiferin) AND (immunomodulator)." The literature used is an article published in the last ten years. Fig. 2 showed the flow chart of this systematic review 


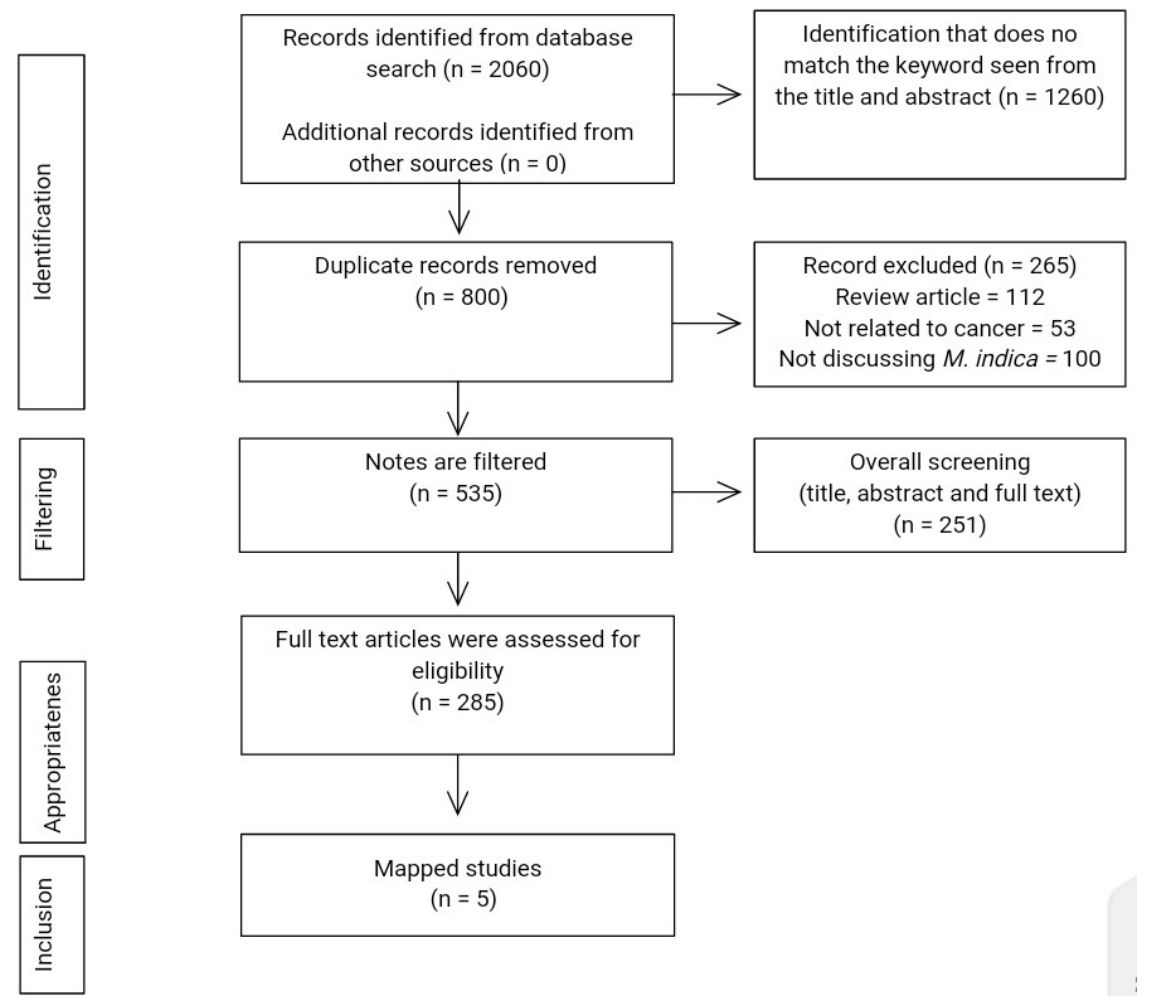

Fig. 2: Flow chart systematic review

\section{Selection of articles}

There are 2060 articles obtained from search results using keywords for articles published in the last ten years $(0$ articles from the Cochrane Library, 1416 articles from Google Scholar, two articles from PubMed, 555 articles from ProQuest, 32 articles from ScienceDirect, and 55 articles from the Wiley Online Library). After screening the title, abstract, and other variables, 285 articles met the inclusion criteria. After screening the full text, six articles meet the requirements, and it used in this review.

\section{Mangiferin as NF-KB inhibitors}

Natural compounds exhibit cytotoxic potential against cancer cells by causing apoptosis and suppressing Nuclear factor-kappa B (NF- $\mathrm{KB}$ ) [33]. NF- $\mathrm{KB}$ is a transcription factor in the immune system with an anti-apoptotic effect, which works to increase the resistance of cancer cells [34]. Activation of NF- $\kappa B$ will increase the formation of TNF- $\alpha$ and IL-1 [35]. NF- $\kappa$ B is commonly used to promote tumor formation and regulate angiogenesis [36].

A study by du Plessis-Stoman et al. shows mangiferin act as NF- $\mathrm{kB}$ inhibitor and cause a reduction in NF- $\mathrm{KB}$ activation in cancer cells. Furthermore, the combination of oxaliplatin-mangiferin $10 \mu \mathrm{g} \mathrm{mol} / \mathrm{l}$ increases $\mathrm{IC}_{50}$ in resistance cancer cells by modulating NF- $\kappa \mathrm{B}$. Mangiferin increased the percentage of dead cells with leakage of the cell membrane, with less necrosis occurred. These results suggest that mangiferin emphasizes cell death by apoptosis rather than necrosis [37,38] with oxaliplatin-mangiferin $10 \mu \mathrm{g} \mathrm{mol} / \mathrm{l}[38]$. Polyphenolic compounds such as mangiferin can affect signaling genes in the NF- $\kappa B$ pathway [39]. It inhibits not only NF- $\kappa B$ signaling but also inhibits phosphorylation of the mitogen-activated protein kinase signaling molecule (MAPK), including extracellular signal-regulated kinase (ERK1/2), jun-n terminal kinase (JNK), and p38 [40].

Mangiferin influences the regulation of $\beta$-catenin, EMT, MMP2, and MMP9

Administration of mangiferin $300 \mu \mathrm{M}$ in ovarian clear cell endocervix (ES-2) produces an anti-MMP effect. It can inhibit the process of invasion, metastasis, angiogenesis in tumor cells.
Mangiferin has also inhibited the $\beta$-catenin pathway, which plays an important role in anticancer activity [41]. $\beta$-catenin is a dual-function protein involved in regulating and coordinating cell adhesion and gene transcription, which plays an important role in the survival and regeneration of cells [42]. $\beta$-catenin modulates the proliferation of epithelial-mesenchymal transition cells (EMT) and matrix metalloproteinases (MMP). EMT is a process characterized by loss of adhesion with inhibition of closely related cell $\beta$-catenin, thereby leading to metastasis [43]. Meanwhile, MMP has the potential as a therapeutic target for cancer [44]. In the process of metastasis, MMP2 and MMP9 result in extracellular cleavage of matrix proteins in cancer cells by contributing to the epithelial to mesenchymal transition, which is the first step for cancer cells to become abnormal [45].

\section{Mangiferin induces cytotoxicity by regulating LDH, NO, and ROS}

The administration of $70 \mu \mu \mathrm{M}$ mangiferin toxic on rhabdomyosarcoma (RD) cells by using the MTT method. The mangiferin-induced cell death in RD cells is determined by lactate dehydrogenase and nitric oxide, generating reactive oxygen species in mitochondrial membranes [46]. Lactate dehydrogenase (LDH) is an enzyme produced by the cytosol. The increase in this enzyme occurred when the cell membrane was damaged by cytotoxicity. Nitric oxide (NO) plays a role in cellular signaling, and in high concentrations, NO has a cytotoxic effect [47]. NO can regulate many physiological processes that cause damage to DNA, proteins, and lipid molecules, leading to apoptosis [48]. One of the NO targets for maintaining thiol status and modulation of cell proliferation is glutathione (GSH) [49]. Research shows that NO induce GSH to make cells sensitive to cytotoxicity [50]. GSH forms oxidation products due to mangiferin, which leads to reactive oxygen species (ROS) generation. ROS plays a vital role in inducing cancer cell apoptosis [51]. Administration of $0.5 \mu \mathrm{M}$ mangiferin to Mia-PaCa2 cells showed a significant increase in ROS levels so that it could induce apoptosis in cancer cells [52].

\section{Mangiferin inhibits the activation of classic macrophages}

Polarized macrophages release a large number of proinflammatory cytokines, including tumor necrosis factor-alpha (TNF- $\alpha$ ), 
interleukin-1 beta (IL-1 $\beta$ ), interleukin-6 (IL-6), and interleukin-8 (IL-8). Proinflammatory cytokines play an important role in the immune system response. Excessive production of cytokines will cause tissue and cell damage to induce cancer cell death through the proliferation process. Studies show that the levels of TNF- $\alpha$, IL-1 $\beta$, IL-6, and IL-8 in THP-1 cells can be reduced by stimulating lipopolysaccharides/interferon-gamma (LPS/IFN- $\gamma$ ) [53]. Administration of mangiferin 100 and $200 \mu \mathrm{mol} / \mathrm{l}$ to human THP-1 cells can significantly increase TNF- $\alpha$, IL-1 $\beta$, IL-6, and IL-8 [54]. Mangiferin also plays a role in reducing interferon regulatory factor 5 (IRF5), an important factor in regulating classical macrophage activation [55]. Classical macrophage activation is required for normal protection in the immune response. Thus, mangiferin produces beneficial disease-fighting effects that have potential in cancer therapy [56].

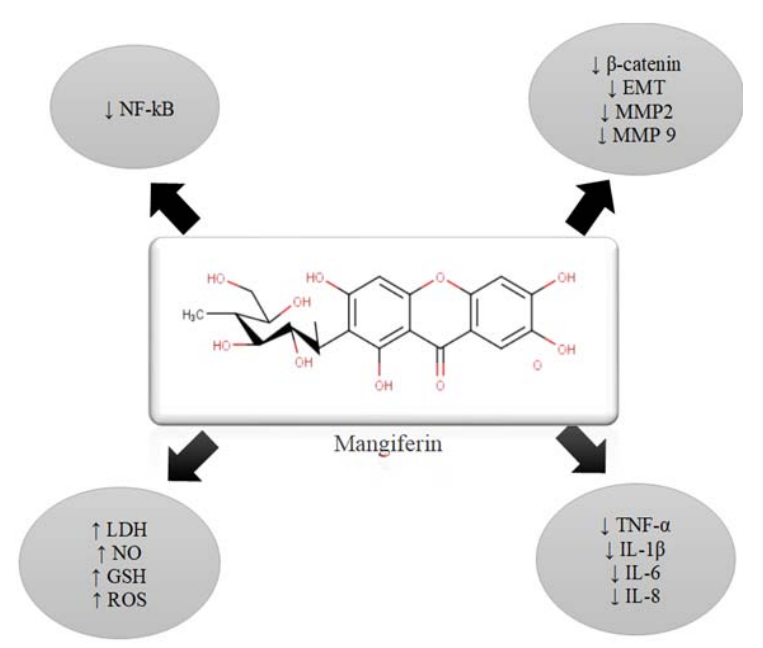

Fig. 3: Mangiferin mechanism to the immune system in cancer

\section{CONCLUSION}

Mangiferin in mango (Mangifera indica L.) potential as candidates drug in cancer. The effect of mangiferin on the immune system can treat cancer through various mechanisms. It works to inhibit NF- $\kappa B$, anti-MMP, cytotoxic induction through LDH, NO, ROS regulation and inhibits the activation of classic macrophages. It can be developed in strategies for cancer therapy that threatens global public health.

\section{FUNDING}

Nil

\section{AUTHORS CONTRIBUTIONS}

All the authors have contributed equally to the literature review, analysis, and interpretation part. The manuscript was written by Ms. Yachi Qurrata Ayuni L, reviewed and edited under the guidance and supervision of Mrs. Fitra Fauziah and Ms. Rezlie Bellatasie. The final version was approved for publication by Mrs. Fitra Fauziah.

\section{CONFLICTS OF INTERESTS}

The authors declare no conflicts of interest.

\section{REFERENCES}

1. Siegel RL, Fedewa SA, Miller KD, Goding-Sauer A, Pinheiro PS, Martinez-Tyson D, Jemal A. Cancer statistics for Hispanics/latinos, 2015. CA Cancer J Clin. 2015;65(6):457-80. doi: 10.3322/caac.21314, PMID 26375877.

2. Salehi B, Fokou PVT, Yamthe LRT, Tali BT, Adetunji CO, Rahavian A, Mudau FN, Martorell M, Setzer WN, Rodrigues CF, Martins N, Cho WC, Sharifi-Rad J. Phytochemicals in prostate cancer: from bioactive molecules to upcoming therapeutic agents. Nutrients. 2019;11(7):1-43. doi: 10.3390/nu11071483, PMID 31261861.
3. Sung H, Ferlay J, Siegel RL, Laversanne M, Soerjomataram I, Jemal A. Issue Information. CA A Cancer J Clin. 2021;71(1):1-2. doi: $10.3322 /$ caac. 21617.

4. Fávaro WJ, Nunes OS, Seiva FRF, Nunes IS, Woolhiser LK, Durán $\mathrm{N}$, Lenaerts AJ. Effects of P-MAPA immunomodulator on toll-like receptors and p53: potential therapeutic strategies for infectious diseases and cancer. Infect Agent Cancer. 2012;7(1):14. doi: 10.1186/1750-9378-7-14, PMID 22709446.

5. Wolchok JD, Chiarion-Sileni V, Gonzalez R, Rutkowski P, Grob JJ, Cowey CL, Lao CD, Wagstaff J, Schadendorf D, Ferrucci PF, Smylie M, Dummer R, Hill A, Hogg D, Haanen J, Carlino MS, Bechter O, Maio M, Marquez-Rodas I, Guidoboni M, McArthur G, Lebbé C, Ascierto PA, Long GV, Cebon J, Sosman J, Postow MA, Callahan MK, Walker D, Rollin L, Bhore R, Hodi FS, Larkin J. Overall survival with combined nivolumab and ipilimumab in advanced melanoma. N Engl J Med. 2017;377(14):1345-56. doi: 10.1056/NEJMoa1709684, PMID 28889792.

6. Jantan I, Ahmad W, Bukhari SNA. Plant-derived immunomodulators: an insight on their preclinical evaluation and clinical trials. Front Plant Sci. 2015;6:655. doi: 10.3389/fpls.2015.00655, PMID 26379683.

7. Chang CY, Leu JD, Wang CY, Chen WR, Lee YJ. The combination of radiotherapy and immunotherapy using glycated chitosan as an immunological stimulant. Biophotonics Immune Resp 2015(9324):1-5.

8. Shang HS, Chen CJ, Shih YL, Peng SF, Chen YL, Liu KC, Huang HC, Hsueh SC, Chen KW, Lu HF, Lee MH, Lee MZ, Lu KW. Mangiferin induces immune responses and evaluates the survival rate in WEHI-3 cell generated mouse leukemia in vivo. Environ Toxicol. 2020;36:77-85. doi: 10.1002/tox.23013, PMID 32889744.

9. Hoesel B, Schmid JA. The complexity of NF- $\mathrm{KB}$ signaling in inflammation and cancer. Mol Cancer. 2013;12:86. doi: 10.1186/1476-4598-12-86, PMID 23915189.

10. Chen X, Song M, Zhang B, Zhang Y. Reactive oxygen species regulate $t$ cell immune response in the tumor microenvironment. Oxid Med Cell Longev. 2016;2016:1580967. doi: 10.1155/2016/1580967. PMID 27547291.

11. Ahmadi M, King JW, Xue SA, Voisine C, Holler A, Wright GP, Waxman J, Morris E, Stauss HJ. CD3 limits the efficacy of TCR gene therapy in vivo. Blood. 2011;118(13):3528-37. doi: 10.1182/blood-2011-04-346338, PMID 21750319.

12. Meanwatthana J. Immune-related adverse events from immune checkpoint inhibitors: a review of risk factors in clinical practice. Pharm Sci Asia. 2020;47(2):104-12. doi: 10.29090/psa.2020.02.019.0095.

13. Piero NM, Joan NM. Cancer: A molecular curse. Int J Curr Pharm Res. 2015;7:1-3.

14. Lueangamornnara U U-pratya Y, Jiratchariyakul W, Kulprom A, O-charoenrat P, Kummalue T. Antiproliferative effects of three roots Thai herbal recipe on human cancer cell lines. Pharm Sci Asia. 2017;44:22-31.

15. Wang LH, Li Y, Yang SN, Wang FY, Hou Y, Cui W, Chen K, Cao Q, Wang S, Zhang TY, Wang ZZ, Xiao W, Yang JY, Wu CF. Gambogic acid synergistically potentiates cisplatin-induced apoptosis in non-small-cell lung cancer through suppressing NF- $\mathrm{kB}$ and MAPK/HO-1 signalling. Br J Cancer. 2014;110(2):341-52. doi: 10.1038/bjc.2013.752, PMID 24300974.

16. Kavitha M, Nataraj J, Essa MM, Memon MA, Manivasagam T. Mangiferin attenuates MPTP induced dopaminergic neurodegeneration and improves motor impairment, redox balance and Bcl-2/Bax expression in experimental Parkinson's disease mice. Chem Biol Interact. 2013;206(2):239-47. doi: 10.1016/j.cbi.2013.09.016, PMID 24095822.

17. Song JH, Bae EY, Choi G, Hyun JW, Lee MY, Lee HW, Chae S. Protective effect of mango (Mangifera indica L.) against UVB-induced skin aging in hairless mice. Photodermatol Photoimmunol Photomed. 2013;29(2):84-9. doi: 10.1111/phpp.12030, PMID 23458392.

18. Ganneru S, Shaik H, Peddi K, Mudiam MKR. Evaluating the metabolic perturbations in Mangifera indica (mango) ripened with various ripening agents/practices through gas chromatography-mass spectrometry based metabolomics. J Sep Sci. 2019;42(19):3086-94. doi: 10.1002/jssc.201900291, PMID 31329331. 
19. Zou B, Wang H, Liu Y, Qi P, Lei T, Sun M, Wang Y. Mangiferin induces apoptosis in human ovarian adenocarcinoma OVCAR3 cells via the regulation of notch3. Oncol Rep. 2017;38(3):1431-41. doi: 10.3892/or.2017.5814, PMID 28714011.

20. Du S, Liu H, Lei T, Xie X, Wang H, He X, Tong R, Wang Y. Mangiferin: an effective therapeutic agent against several disorders [review]. Mol Med Rep. 2018;18(6):4775-86. doi: 10.3892/mmr.2018.9529, PMID 30280187.

21. Gonzalez-Gallego J, Garcia-Mediavilla MV, Sanchez-Campos S, Tunon MJ. Fruit polyphenols, immunity and inflammation. Br J Nutr. 2010;104; Suppl 3:S15-27. doi: 10.1017/S0007114510003910, PMID 20955647.

22. Pandey PK, Ahmed B, Prasad J, Bala M, Khan HA. Radiomodifying action, pharmacokinetic and biodistribution of ethyl 3,4,5-trihydroxybenzoate-implication in development of radiomitigator. Sci Rep. 2019;9(1):18873. doi: 10.1038/s41598-019-55316-2, PMID 31827168.

23. Hewavitharana AK, Tan ZW, Shimada R, Shaw PN, Flanagan BM. Between fruit variability of the bioactive compounds, $\beta$-carotene and mangiferin, in mango ( Mangifera indica ). Nutr Diet. 2013;70(2):158-63. doi: 10.1111/1747-0080.12009.

24. Krishnananda KK, Shabaraya AR. Comparison of antibacterial activity of leaves extracts of (Tectona grandis), (Mangifera indica L.), and (Anacardium occidentale). Int J Curr Pharm Res. 2016;9:36-9.

25. Viswanadh EK, Rao BN, Rao BS. Antigenotoxic effect of mangiferin and changes in antioxidant enzyme levels of Swiss albino mice treated with cadmium chloride. Hum Exp Toxicol. 2010;29(5):409-18. doi: 10.1177/0960327110361752, PMID 20150354.

26. Noratto GD, Bertoldi MC, Krenek K, Talcott ST, Stringheta PC, Mertens-Talcott SU. Anticarcinogenic effects of polyphenolics from mango (Mangifera indica) varieties. J Agric Food Chem. 2010;58(7):4104-12. doi: 10.1021/jf903161g, PMID 20205391.

27. Louisa M, Soediro TM, Suyatna FD. In vitro modulation of P-glycoprotein, MRP-1 and BCRP expression by mangiferin in doxorubicin-treated MCF-7 cells. Asian Pac J Cancer Prev. 2014;15(4):1639-42. doi: 10.7314/apjcp.2014.15.4.1639, PMID 24641381.

28. Bulugonda RK, Kumar KA, Gangappa D, Beeda H, Philip GH, Rao DM. Mangiferin from (Pueraria tuberosa) reduces inflammation via inactivation of NLRP3 inflammasome. Sci Rep 2017;7:1-14.

29. Saleh S, El-Maraghy N, Reda E, Barakat W. Modulation of diabetes and dyslipidemia in diabetic insulin-resistant rats by mangiferin: role of adiponectin and TNF- $\alpha$. An Acad Bras Cienc. 2014;86(4):1935-48. doi: 10.1590/0001-3765201420140212, PMID 25590730.

30. Márquez L, García-Bueno B, Madrigal JLM, Leza JC. Mangiferin decreases inflammation and oxidative damage in rat brain after stress. Eur J Nutr. 2012;51(6):729-39. doi: 10.1007/s00394-011-0252-x, PMID 21986672.

31. Franquesa M, Hoogduijn MJ, Bestard O, Grinyó JM. Immunomodulatory effect of mesenchymal stem cells on $\mathrm{B}$ cells. Front Immunol. 2012;3:212. doi: 10.3389/fimmu.2012.00212, PMID 22833744.

32. Gavaraskar K, Dhulap S, Hirwani RR. Therapeutic and cosmetic applications of evodiamine and its derivatives--a patent review. Fitoterapia. 2015;106:22-35. doi: 10.1016/j.fitote.2015.07.019, PMID 26255828.

33. Khurana RK, Gaspar BL, Welsby G, Katare OP, Singh KK, Singh B. Improving the biopharmaceutical attributes of mangiferin using vitamin E-TPGS co-loaded self-assembled phosholipidic nano-mixed micellar systems. Drug Delivery Transl Res. 2018;8(3):617-32. doi: 10.1007/s13346-018-0498-4, PMID 29637488.

34. Tafani M, Pucci B, Russo A, Schito L, Pellegrini L, Perrone GA. Modulators of HIF- $1 \alpha$ and NFKB in cancer treatment: is it a rational approach for controlling malignant progression. Front Pharmacol. 2013;4:1-12.

35. Hou J, Zheng D, Fung G, Deng H, Chen L, Liang J, Jiang Y, Hu Y. Mangiferin suppressed advanced glycation end products (AGEs) through NF- $\mathrm{B}$ deactivation and displayed anti-inflammatory effects in streptozotocin and high fat diet-diabetic cardiomyopathy rats. Can J Physiol Pharmacol. 2016;94(3):332-40. doi: 10.1139/cjpp-2015-0073, PMID 26751764.

36. Xia Y, Shen S, Verma IM. NF- $\mathrm{B}$, an active player in human cancers. Cancer Immunol Res. 2014;2(9):823-30. doi: 10.1158/2326-6066.CIR-14-0112, PMID 25187272.

37. du Plessis-Stoman D, du Preez JGH, van de Venter M. Combination treatment with oxaliplatin and mangiferin causes increased apoptosis and downregulation of NFKB in cancer cell lines. Afr J Tradit Complement Altern Med. 2011;8(2):177-84. doi: 10.4314/ajtcam.v8i2.63206, PMID 22238500.

38. Du M, Wen G, Jin J, Chen Y, Cao J, Xu A. Mangiferin prevents the growth of gastric carcinoma by blocking the PI3K-Akt signalling pathway. Anticancer Drugs. 2018;29(2):167-75. doi: 10.1097/CAD.0000000000000583, PMID 29215373.

39. Sekiguchi Y, Mano H, Nakatani S, Shimizu J, Kataoka A, Ogura K, Kimira Y, Ebata M, Wada M. Mangiferin positively regulates osteoblast differentiation and suppresses osteoclast differentiation. Mol Med Rep. 2017;16(2):1328-32. doi: 10.3892/mmr.2017.6752, PMID 28627701.

40. Zheng Z, Lin C, Wang S, Wang P, Xu W, Ma W, et al. Suppressive activities of mangiferin on human epithelial ovarian cancer. Phytomedicine. 2020;76:. 153267PMID 153267.

41. Valenta T, Hausmann G, Basler K. The many faces and functions of $\beta$-catenin. EMBO J. 2012;31(12):2714-36. doi: 10.1038/emboj.2012.150, PMID 22617422.

42. Cai Z, Cao Y, Luo Y, Hu H, Ling H. Signalling mechanism(s) of epithelial-mesenchymal transition and cancer stem cells in tumour therapeutic resistance. Clin Chim Acta. 2018;483:156-63. doi: 10.1016/j.cca.2018.04.033, PMID 29709449.

43. Li H, Huang J, Yang B, Xiang T, Yin X, Peng W, et al. Mangiferin exerts antitumor activity in breast cancer cells by regulating matrix metalloproteinases, epithelial to mesenchymal transition, and $\beta$-catenin signaling pathway. Toxicol Appl Pharmacol. 2013;272(1):180-90. 10.1016/j.taap.2013.05.011, PMID 23707762.

44. Jacob A, Jing J, Lee J, Schedin P, Gilbert SM, Peden AA, Junutula JR, Prekeris R. Rab40b regulates trafficking of MMP2 and MMP9 during invadopodia formation and invasion of breast cancer cells. J Cell Sci. 2013;126(20):4647-58. doi: 10.1242/jcs.126573, PMID 23902685.

45. Padma VV, Kalaiselvi P, Yuvaraj R, Rabeeth M. Mangiferin induces cell death against rhabdomyosarcoma through sustained oxidative stress. Integr Med Res. 2015;4(2):66-75. doi: 10.1016/j.imr.2014.09.006, PMID 28664112.

46. Kamm A, Przychodzen P, Kuban-Jankowska A, Jacewicz D, Dabrowska AM, Nussberger S, et al, Wozniak M, Gorska-Ponikowska M. Nitric oxide and its derivatives in the cancer battlefield. Nitric Oxide-Biol Chem. 2019;93:102-14. doi: 10.1016/j.niox.2019.09.005, PMID 31541733.

47. Choudhari SK, Chaudhary M, Bagde S, Gadbail AR, Joshi V. Nitric oxide and cancer: Aa review. World J Surg Oncol. 2013;118:1-11. doi: 10.1186/1477-7819-11-118, PMID 23718886.

48. Aquilano K, Baldelli S, Cardaci S, Rotilio G, Ciriolo MR. Nitric oxide is the primary mediator of cytotoxicity induced by GSH depletion in neuronal cells. J Cell Sci. 2011;124(7):1043-54. doi: 10.1242/jcs.077149, PMID 21363890.

49. Dubey M, Nagarkoti S, Awasthi D, Singh AK, Chandra T, Kumaravelu J, Barthwal MK, Dikshit M. Nitric oxide-mediated apoptosis of neutrophils through caspase-8 and caspase-3-dependent mechanism. Cell Death Dis. 2016;7(9):1-12e2348. doi: 10.1038/cddis.2016.248, PMID 27584786.

50. Liou GY, Storz P. Reactive oxygen species in cancer. Free Radical Res. 2010;44(5):479-96. doi: 10.3109/ 10715761003667554, PMID 20370557.

51. Yu L, Chen M, Zhang R, Jin Z. Inhibition of cancer cell growth in gemcitabine-resistant pancreatic carcinoma by mangiferin phytochemical involves induction of autophagy, endogenous ROS production, cell cycle disruption, mitochondrial-mediated apoptosis and suppression of cancer cell migration and invasion. J BUON. 2019;24(4):1581-6. PMID 31646812. 
52. Park KR, Bryers JD. Effect of macrophage classical (M1) activation on implant-adherent macrophage interactions with Staphylococcus epidermidis: a murine in vitro model system. J Biomed Mater Res A. 2012;100(8):2045-53. doi: 10.1002/jbm.a.34087, PMID 22581669.

53. Wei Z, Yan L, Chen Y, Bao C, Daeng J, Deng J. Mangiferin inhibits classical macrophage activation via downregulating interferon regulatory factor 5 expression. Mol Med Rep. 2016;14(2):1091-8. doi: 10.3892/mmr.2016.5352, PMID 27277156.

54. Wang LX, Zhang SX, Wu HJ, Rong XL, Guo J. M2b macrophage polarization and its roles in diseases. J Leukoc Biol. 2019;106(2):345-58. doi: 10.1002/JLB.3RU1018-378RR, PMID 30576000 .
55. Jarvis JN, Meintjes G, Bicanic T, Buffa V, Hogan L, Mo S, et al, Tomlinson G, Kropf P, Noursadeghi M, Harrison TS. Cerebrospinal fluid cytokine profiles predict risk of early mortality and immune reconstitution inflammatory syndrome in HIV-associated Cryptococcal meningitis. PLoOS Pathog. 2015;11(4):1-18e1004754. 10.1371/journal.ppat.1004754, PMID 25853653.

doi:

56. Huang Y, Gao J, Meng XM, Jiang GL, Yang YR, Li H, Liu J, Li J. Involvement of mitogen-activated protein kinase activation in cyclooxygenase- 2 and transforming growth factor- $\beta$ production in alveolar macrophage from chronic bronchitis rats. Immunopharmacol Immunotoxicol. 2011;33(4):645-51. doi: 10.3109/08923973.2011.557383, PMID 21428715. 